\title{
EKSPLORASI POTENSI EKSTRAK BIJI ALPUKAT (PERSEA AMERICANA) SEBAGAI AGEN ANTIINFLAMASI
}

\author{
Della Tinesya ${ }^{1}$, Nurma Andhita ${ }^{2}$, Rizal Vidmar ${ }^{3}$ \\ STKIP PGRI Tulungagung ${ }^{1,2,3}$ \\ dellatinesya02@gmail.com ${ }^{1}$, nurmaandhita30@gmail.com², rizalvidmar021@gmail.com ${ }^{3}$
}

\begin{abstract}
ABSTRAK
Inflamasi adalah reaksi lokal jaringan terhadap infeksi atau cedera. Penyebabnya antara lain terbakar, toksin, gigitan serangga, produk bakteri, atau pukulan keras. Inflamasi dapat bersifat akut (jangka pendek) atau kronik (berlangsung lama). Tandatanda lokal respons inflamasi yaitu panas, kemerahan, bengkak, nyeri, atau kehilangan fungsi. Sedangkan, antiinflamasi adalah obat yang dapat menghilangkan peradangan yang disebabkan bukan karena aktivitas mikroorganisme (non infeksi). Tujuan penelitian ini adalah untuk mengetahui potensi ekstrak biji alpukat sebagai agen antiinflamasi. Pengujian dilakukan dengan memberikan beberapa bahan uji secara oral seperti aquades, larutan natrium diklofenak, kelompok ekstrak biji alpukat, dengan dosis berbeda kepada hamster sesuai kelompoknya. Masing-masing kelompok hamster disuntikkan karagenan $1 \%$ sebanyak 0,1 ml pada kaki kanan hamster. Analisis data hasil penelitian dilakukan dengan menghitung AUC dari ketebalan udema pada kaki hamster. Hasil dari penelitian ini menunjukkan bahwa ekstrak biji Persea americana memiliki efek antiinflamasi.
\end{abstract}

Kata kunci: ekstraksi, biji alpukat, antiinflamasi

\section{ABSTRACT}

Inflammation is a local tissue reaction to infection or injury. It caused by being burning, toxins, insect bites, bacterial products, or hard blows. Inflammation can be acute (short term) or chronic (long lasting). Local signs of an inflammatory response are heat, redness, swelling, pain, or loss of function. While, anti-inflammatory is a drug that can eliminate inflammation caused by non-microorganisms activity (non-infection). The purpose of this study was to determine the potential of avocado seed extract as an antiinflammatory agent. The test is carried out by giving some oral test materials such as aquades, diclofenac sodium solution, avocao seed extract group, with different doses to hamsters according to their group. Each group of hamsters is injected 1\% carragenan as much as $0.1 \mathrm{ml}$ on the right leg of the hamster. Data analysis was performed by calculating AUC of the thickness of the edema in the hamster's feet. The results of the study indicate that the Persea aericana seed extract has an anti-inflammatory effect.

Keywords: extraction, avocado seeds, anti-inflammatory

\section{PENDAHULUAN}

Indonesia terkenal akan kekayaan sumber daya alam, baik flora maupun fauna. Hal tersebut dapat dilihat bahwa hampir semua penduduk Indonesia memusatkan perhatiannya pada sektor pertanian baik di laut maupun di darat. Kekayaan alam Indonesia terutama berasal dari tumbuh-tumbuhan yang dapat digunakan sebagai bahan obat, pangan, buah-buahan, rempah-rempah, bangunan, industri, dan sebagianya. 
Berbagai macam tumbuhan memang sudah digunakan sebagai tanaman obat sejak zaman dahulu, mengingat biaya pengobatan yang tidak terjangkau oleh semua orang, pengobatan alamiah dengan tanaman obat tradisional dipandang sebagai alternatif yang terjangkau. Seperti halnya buah alpukat. Buah alpukat (Persea americana) dapat digunakan sebagai obat. Diketahui bahwa masyarakat memanfaatkan alpukat hanya bagian buahnya saja untuk dikonsumsi, sedangkan bijinya dibuang. Namun ternyata, biji alpukat dapat untuk sebagai alternatif untuk pengobatan penyakit, salah satunya sebagai antiinflamasi.

Inflamasi merupakan usaha tubuh untuk menginaktivasi atau merusak zat organisme yang menyerang, menghilangkan zat iritan, dan mengatur perbaikan jaringan (Karch, 2003). Saat inflamasi terjadi, terdapat proses dimana senyawa-senyawa radikal bebas dihasilkan. Sebenarnya radikal bebas merupakan bagian dari proses alami dalam tubuh. Radikal bebas juga dapat bersumber dari luar tubuh. Kadar radikal bebas yang diimbangi dengan antioksidan tidak berbahaya, tetapi dapat membahayakan jika radikal bebas melebihi kadar yang dapat ditangani tubuh hingga menimbulkan kerusakan. Radikal bebas dapat menyerang dan menimbulkan kerusakan pada berbagai sel tubuh. Asam nukleat, lipid, dan protein adalah unsur-unsur yang bisa terkena dampaknya. Gejala-gejala yang biasa dijumpai pada inflamasi yaitu nyeri, bengkak, panas, kemerahan, dan malfungsi sel. Hal tersebut membuat penderita merasa tidak nyaman, maka dari itu perlu dilakukan penanganan (Supriyana et al., 2015).

Biji buah alpukat diketahui mengandung senyawa polifenol, flavonoid, triterponoid, kuionon, tanin, saponin, monoterpenoid, dan seskuiterpenoid. Polifenol berperan sebagai antioksidan, sehingga diduga mampu menghambat aktivasi karsinogen dan mengurangi risiko terjangkitnya penyakit kronis. Penelitian secara in vivo maupun in vitro menunjukkan bahwa flavonoid memiliki aktivitas biologis maupun farmakologis, antara lain bersifat sebagai antiradang, antibakteri, antialergi, antioksidan, antikarsinogen, dan melindungi pembuluh darah. Penggunaan flavonoid di bidang kedokteran telah banyak dilakukan, misalnya pada pengobatan diabetes mellitus, penyakit inflamasi, penyakit alergi, kanker, infeksi yang disebabkan oleh virus, tukak lambung, kardiovaskuler, dan osteoporosis.

Selama ini, mayoritas masyarakat memanfaatkan alpukat hanya bagian buahnya saja, sedangkan kulit dan bijinya langsung dibuang. Berdasarkan penelitian yang ada, biji alpukat ternyata memiliki kandungan zat yang bermanfaat bagi tubuh dan dapat digunakan sebagai alternatif pengobatan. Oleh karena itu, fokus penelitian ini adalah untuk mengeksplorasi potensi ekstrak biji alpukat bila digunakan sebagai agen antiinflamasi.

\section{METODE}

\section{Waktu dan Tempat Pelaksanaan}

Penelitian ini dilaksanakan selama 5 bulan bertempat di Laboratorium IPA STKIP PGRI Tulungagung.

\section{Tahap Penelitian}

1. Penyiapan bahan

Bahan penelitian yang digunakan antara lain etanol 96\%, karagenan, aquades, biji alpukat yang sudah dikeringkan, natrium diklofenak $50 \mathrm{mg}$, hamster. Alat-alat yang digunakan dalam penelitian ini adalah jangka sorong, gelas kimia, spuit injeksi, sonde oral, batang pengaduk, kawat kasa, panci, termometer, kertas saring, ayakan, blender, cawan porselen, sendok, kompor gas, tabung gas, sarung tangan, masker, timbangan analitik.

2. Proses ekstraksi 
Biji alpukat dibersihkan dengan dicuci bersih. Kemudian dipotong menjadi tipis-tipis, lalu dijemur hingga kering. Biji alpukat yang sudah kering tersebut dihaluskan menggunakan blender dan diayak. Sebanyak 150 gram serbuk biji alpukat dibagi menjadi 2 bagian, dan direndam dengan $150 \mathrm{~mL}$ etanol 96\%. Serbuk biji alpukat yang sudah direndam dengan etanol, kemudian dipanaskan menggunakan api kecil dengan suhu $\pm 70^{\circ} \mathrm{C}$ selama \pm 1 jam. Kemudian ekstrak dipindahkan di kertas saring, dan disaring agar didapat ekstrak kental.

3. Pengujian ekstrak

Pengujian ekstrak biji alpukat dilakukan dengan menggunakan hamster sebagai hewan uji. Hamster tersebut dipuasakan selama \pm 12 jam sebelum pengujian, air minum tetap diberikan. Pengosongan lambung bermanfaat terhadap proses absorpsi obat. Hamster ditimbang dan pada mata kaki kanan diberi tanda, lalu diukur menggunakan jangka sorong.

$$
\text { Hamster dikelompokkan }
$$
menjadi 4 kelompok. Keempat kelompok adalah kelompok aquades, larutan natrium diklofenak, kelompok ekstrak etanol. Keempat senyawa tersebut diberikan kepada hamster sesuai kelompoknya masing-masing dengan menggunakan sonde oral dan diberi jeda waktu selama 15 menit. Kelompok aquades dengan dosis sebesar $5 \mathrm{~mL} / \mathrm{kgBB}$, kelompok natrium diklofenak $10 \mathrm{mg} / \mathrm{kgBB}$, Tabel 1 Hasil Uji pada Menit ke-30

\begin{tabular}{lcc}
\hline \multicolumn{1}{c}{ Kelompok } & Berubah & Tidak berubah \\
\hline Kontrol negatif (aquades) & & $\checkmark$ \\
\hline Kontrol positif (natrium deklofenak) & $\checkmark$ & \\
\hline $\begin{array}{l}\text { Ekstrak etanol biji alpukat sebesar 200 } \\
\text { mg/kgBB }\end{array}$ & $\checkmark$ & \\
\hline $\begin{array}{l}\text { Ekstrak etanol biji alpukat sebesar 300 } \\
\text { mg/kgBB }\end{array}$ & $\checkmark$ & \\
\hline
\end{tabular}

kelompok ekstrak biji alpukat dengan dosis $200 \mathrm{mg} / \mathrm{kgBB}$, dan kelompok ekstrak biji alpukat dengan dosis 300 $\mathrm{mg} / \mathrm{kgBB}$.

Dengan $0,1 \quad \mathrm{~mL}$ larutan karagenin $1 \%$, hamster diinjeksi dengan karagenan, kemudian diamati selama 3 jam setiap 30 menit. Hamster dikelompokkan menjadi 4 kelompok. Selang 30 menit kemudian diukur menggunakan jangka sorong.

4. Analisis data

Analisis data hasil uji dilakukan dengan dibandingkan antara perlakuan bahan uji mana yang efektif bila digunakan sebagai antiinflamasi. Rumus perhitungannya adalah :

$$
\begin{aligned}
& \mathrm{AUC}_{0-\mathrm{x}}=\left(\frac{C 1-C 0}{2} \times t 1-t 0\right)+ \\
& \left(\frac{C 2-C 1}{2} \times t 2-t 1\right)+\ldots+\left(\frac{C_{n}-C_{n-1}}{2} \times\right. \\
& \left.t_{n}-t_{n-1}\right)
\end{aligned}
$$

Keterangan :

$$
\begin{aligned}
\text { AUC }_{0-\mathrm{x}}= & \text { Area Under Cuve dari } \\
& \text { ketebalan telapak kaki } \\
& \text { hamster ke-0 sampai } \\
& \text { menit ke-180. } \\
\mathrm{C}_{\mathrm{n}}-\mathrm{C}_{\mathrm{n}-1}= & \text { Besarnya tebal udem dari } \\
& \text { menit ke-0 sampai menit } \\
& \text { ke-180. } \\
t_{n}-t_{n-1}= & \text { Lamanya waktu } \\
& \text { pengukuran mulai dari } \\
& \text { menit ke-0 sampai menit } \\
& \text { ke-180. }
\end{aligned}
$$


Tabel 2 Hasil Uji pada Menit ke-60

\begin{tabular}{lcc}
\hline \multicolumn{1}{c}{ Kelompok } & Berubah & Tidak berubah \\
\hline Kontrol negatif (aquades) & & $\checkmark$ \\
\hline Kontrol positif (natrium diklofenak) & $\checkmark$ & \\
\hline $\begin{array}{l}\text { Ekstrak etanol biji alpukat sebesar 200 } \\
\text { mg/kgBB }\end{array}$ & $\checkmark$ & \\
\hline $\begin{array}{l}\text { Ekstrak etanol biji alpukat sebesar 300 } \\
\text { mg/kgBB }\end{array}$ & $\checkmark$ \\
\hline
\end{tabular}

Tabel 3 Hasil Uji pada Menit ke-150

\begin{tabular}{lcc}
\hline \multicolumn{1}{c}{ Kelompok } & Berubah & Tidak berubah \\
\hline Kontrol negatif (aquades) & & $\checkmark$ \\
\hline Kontrol positif (natrium diklofenak) & $\checkmark$ & \\
\hline $\begin{array}{l}\text { Ekstrak etanol biji alpukat sebesar 200 } \\
\text { mg/kgbb }\end{array}$ & $\checkmark$ & \\
\hline $\begin{array}{l}\text { Ekstrak etanol biji alpukat sebesar 300 } \\
\text { mg/kgbb }\end{array}$ & $\checkmark$ & \\
\hline
\end{tabular}

\section{HASIL}

Dalam pengujian inflamasi, dipilih menggunakan metode induksi udema dengan alat ukur jangka sorong. Dipilih jangka sorong karena jangka sorong lebih sederhana, memiliki reprodubilitas tinggi, dan mudah dibandingkan dengan alat ukur lain. Untuk membentuk udem pada kaki hamster, dibutuhkan senyawa karagenan sebesar $1 \%$ dikarenakan karagenan memiliki efek yang cepat, penginduksi inflamasi akut, dapat diamati dengan baik, tidak meninggalkan bekas dan kerusakan jaringan, serta biasa digunakan dalam uji inflamasi. Dan digunakan konsentrasi $1 \%$ karena karagenan sudah mampu menimbulkan efek inflamasi pada konsentrasi tersebut. Pemberian aquades pada hamster menunjukkan perbedaan tidak bermakna saat pengujian efek antiinflamasi. Oleh karena itu, dalam pengujian ekstrak etanol biji alpukat ini digunakan kontrol negatif aquades. Penggunaan aquades sebagai kontrol negatif adalah untuk membuktikan apakah ada perubahan sebagai antiinflamasi atau tidak.
Selanjutnya sebagai kontrol positif digunakan natrium diklofenak yang sudah dihaluskan. Hal ini bertujuan agar natrium diklofenak lebih mudah larut dalam air dan lebih mudah diserap oleh tubuh hamster. Penggunaan natrium diklofenak ini bertujuan untuk membandingkan seberapa besar efek penyembuhan inflamasi jika dibandingkan dengan ekstrak biji alpukat, karena natrium diklofenak ini mengandung senyawa yang bertugas sebagai antiinflamasi.

\section{PEMBAHASAN}

Dari penelitian yang telah dilakukan dapat disimpulkan bahwa ekstrak etanol biji alpukat $300 \mathrm{mg} / \mathrm{kgBB}$ memiliki pengaruh yang lebih besar dibandingkan dengan dosis 200 $\mathrm{mg} / \mathrm{kgBB}$. Adanya kemampuan ekstrak etanol biji alpukat sebagai agen antiinflamasi pada hamster yang diberi karagenan disebabkan karena adanya senyawa yang terdapat dalam ekstrak biji alpukat. Jenis senyawa yang dapat berfungsi sebagai antiinflamasi adalah flavonoid karena flavonoid dapat 
menangkap radikal bebas yang menimbulkan munculnya respon-respon inflamasi. Senyawa yang berfungsi menangkap radikal bebas dalam tubuh dapat disebut sebagai antioksidan.

\section{KESIMPULAN}

Ekstrak etanol biji alpukat memiliki potensi bila digunakan sebagai agen antiinflamasi pada hamster yang terinduksi karagenan.

\section{SARAN}

Penelitian terhadap ekstraksi biji alpukat ini dapat dijadikan sebagai obat antiinflamasi, agar kecenderungan masyarakat dalam mengonsumsi obat dari bahan - bahan kimia dapat berkurang.

\section{REFERENSI}

Cakrabauana, H. 2011. Uji Aktifitas Antioksidan dan Identifikasi Senyawa Aktif Ekstrak Tanaman Anting-Anting (Acalypha indica L.). Malang: Jurusan Kimia Fakultas Sains dan Teknologi Universitas Islam Negeri Maulana Malik Ibrahim.

Hariyana, A. 2008. Tumbuhan Obat dan Khasiatnya. Cet. VI. Jakarta: Penebar Swadaya.

Kumar, V., Abbas, A.K., dan Fausto, N., 2005. Robbins and Cotran Pathologic Basic of Diseases, $7^{\text {th }}$ Edition. Philadelphia, Elsevier Saunders, 43-45.

Malangngi, L.P., M.S., dan Paendong J.J.E., 2012. Penentuan Kandungan Tanin dan Uji Aktivitas Antioksidan Ekstrak Biji Buah Alpukat (Persea americana Mill.). Jurnal Kimia FMIPA Unsrat, 1(1), 5-10.

Rinayanti A, Dewanti E, Adelina M. 2014. Uji Efek Antiinflmasi Fraksi Air Daun Mahkota Dewa (Phaleria macrocarpa (Shecff.) Boerl.) terhadap Tikus Putih (Rattus norvegicus L.). Pharm Sci Res. 1(2):78-85.
Robinson, T. 1995. Kandungan Organik Tumbuhan Tingkat Tinggi. Bandung: Penerbit ITB Bandung

Sabir, A., 2003. Pemanfaatan Flavonoid di Bidang Kedokteran Gigi. Majalah Kedokteran Gigi (Dental Journal), Edisi Khusus Temu Ilmiah Nasional III, 81-87.

Supriyatna, Febriyanti, R., Dewanto, Wijaya, I., dan Ferdiansyah, F., 2015. Fitoterapi Sistem Organ: Pandangan Dunia Barat terhadap Obat Herbal Global, Edisi 2. Yogyakarta, CV. Budi Utama, 223224.

Sutrisna, EM., D. F. Widyasari dan Suprapto. 2010. Uji Efek Anti Inflamasi Ekstrak Etil Asetat Buah Semu Jambu Mete (Ana cardium Occidentale L.) Terhadap Edema pada Telapak Kaki Tikus Putih (Rattus Norvegicus) Jantan yang Diinduksi Karagenin. Biomedika 2 (1) : 33-37.

Sukmawati, Yuliet, dan Ririen Hardani. 2015. Uji Aktivitas Antiinflamasi Ekstrak Etanol Daun Pisang Ambon (Musa paradisiaca L.) terhadap Tikus Putih yang Diinduksi Karagenan. GALENIKA Journal of Pharmacy Vol. 1 (2) : 126-132

Tjandrawinata, R.R., Djunarko, I., Fenty, dan Hendra, P., 2015. Antiinflamation Effects of Bioactive Fraction DLBSO533 Containing Phaleria Macrocarpa and Nigella Sativa on Animal Model. International Journal of Pharmacy and Pharmaceutical Sciences., 7(1), $1-4$. 